\author{
${ }^{1}$ B.A. Belgibaev ${ }^{(1 D}$ V.V. Nikulin ${ }^{2},{ }^{3}$ A.A. Umarov \\ ${ }^{1}$ Doctor of Technical Sciences, Docent, Al-Farabi Kazakh National University, \\ Almaty, Kazakhstan, E-mail: bbelgibaev@list.ru \\ ${ }^{2} \mathrm{PhD}$ doctor, Associate Professor, State University of New York, \\ Binghamton, USA, E-mail: vnikulin@binghamton.edu \\ ${ }^{3} \mathrm{PhD}$ student, Al-Farabi Kazakh National University, \\ Almaty, Kazakhstan, E-mail: uaa_77@mail.ru
}

\title{
DESIGNING SMART GREENHOUSES, SATISFACTORY PRICE-QUALITY
}

Smart greenhouse is a revolution in agriculture, which creates a self-regulating microclimate suitable for plant growth through the use of sensors, actuators and control and management systems that optimize growth conditions and automate the growing process. The global smart greenhouse market was valued at approximately 680.3 million in 2016 and is expected to reach approximately 1.31 billion by 2022, an increase of $14.12 \%$ on average between 2017 and 2022 .

However, high installation prices and high upfront investment costs can constrain greenhouse adoption in many underdeveloped and developing countries. Therefore, the urgent task is the development and implementation of smart greenhouses that are suitable for the wider population, which provide the population with vegetables and fruits seasonally or year-round. Improving the quality of service of greenhouses, controlling and monitoring microclimate processes is possible through the use of programmable logic controllers, modern smart, wireless and web technologies WSN and IoT.

The article is devoted to the design of the Home Smart Greenhouse system, the control device of which is implemented on the basis of NLC. The system allows you to perform a) control (monitoring) of microclimate processes in Online mode; b) fuzzy control in manual and automatic mode; c) adjust the parameters of the three microclimate processes: cooling, watering and lighting.

The described NLC model adequately reflects the microclimate control process in the greenhouse. As a result of using the system, the productivity of the farmer user is increased, thereby helping the farmer user control the plant growth process and take the necessary measures to care for them. The developed system meets the criterion of price-quality, that is, it is simultaneously accessible to the population, and at the same time has an acceptable quality of service, using wireless network and web technologies (WSN, IoT) and fuzzy control. The cost of the system is 86.75 (the price is not higher than the minimum wage of Kazakhstan), the economic effect of using the system is 25 , the payback period of the greenhouse is 4 seasons.

Key words: smart greenhouse, price-quality criterion, fuzzy logic controller (NLC), WSN, IoT, ESP 32, Matlab.

\author{
${ }^{1}$ Б.А. Бельгибаев, ${ }^{2}$ В.В. Никулин, ${ }^{3}$ А.А. Умаров \\ ${ }^{1}$ т.ғ.д., доцент, әл-Фараби атындағы Қазақ ұлттық университеті, \\ Алматы қ, Қазақстан, E-mail: bbelgibaev@list.ru \\ ${ }^{2} \mathrm{PhD}$ докторы, ассоциативті профессор, Нью Йорк мемлекеттік университеті, \\ Бингамтон қ., АҚШ, E-mail: vnikulin@binghamton.edu \\ ${ }^{3} \mathrm{PhD}$ докторанты, әл-Фараби атындағы Қазақ ұлттқ университеті, \\ Алматы қ., Қазақстан, E-mail: uaa_77@mail.ru
}

Сапа-баға критериін қанағаттандыратын ақылды жылыжайды жобалау 
Ақылды жылыжай - датчиктерді, атқарушы құралдар мен бақылау/басқару жүйелерін пайдаланып, өсімдіктерге ыңғайлы микроклимат жасайтын және өсу процесін оңтайлы етіп, автоматтандыру қызметін атқаратын ауыл шаруашылығындағы төңкеріс. Ақылды жылыжайдың әлемдік нарығы 2016 ж. 680,3 млн. доллар құрап, 2022 ж. 1,31 млрд. долларға жетеді деген болжам бар, яғни, 2017-2022 жж. аралығында орташа есеппен 14,12\% өсуі мүмкін.

Алайда, орнатуға және алғашқы инвестицияларға кететін шығындар әлсіз дамыған және дамып келе жатқан мемлекеттерде жылыжайлады ендіру процесін шектейді. Сондықтан, халықты мауысым бойы немесе жыл бойы көкөністер мен жеміс-жидектермен қамтамасыз ететін қолжетімді ақылды жылыжай құру және ендіру өзекті мәселе болып табылады. Жылыжайларды сапалы қамтамасыз ету, бақылау және басқару бағдарламаланатын логикалық контроллерлер, заманауи смарт, WSN/IoT сымсыз және веб технологияларды пайдалану арқылы мүмкін болады.

Мақала "Үйдегі ақылды жылыжай" жүйесін жобалауға арналады, оның басқару құралы анық емес логикалық контроллер (АЕЛК) негізделген. Жүйе келесі қызметтерді атқарады: a) Online тәртібінде микроклимат процестерін бақылау (мониторинг); ә) қолмен және автоматты тәртіпте микроклимат процестерін басқару; б) микроклиматтың үш процестерінің параметрлерін реттеу: суыту, суару және жарықтандыру.

Сипатталған AEK моделі жылыжайдайдағы микроклимат процестерін басқаруды дұрыс, ақылға сай көрсетеді. Жүйені пайдалану нәтижесінде пайдаланушы-бағбанның еңбек өнімділігі өседі, ол өсімдіктің өсу процесін бақылап, өсімдікке күтім жасау бойынша тиісті шаралар қабылдай алады.

Құрастылырған жүйе баға-сапа критерийін қанағаттандырады, яғни, пайдаланушы үшін қолжетімді және заманауи смарт, WSN/IoT сымсыз және веб технологияларды пайдалану арқылы жеткілікті деңгейде сапалы болып табылады. Жүйенің бағасы 86.75 (бағасы қазақстандықтың ең кіші жалақысынан аз), жүйені пайдаланудың экономикалық тиімділігі - 25, өтеу мерзімі - 4 мауысым.

Түйін сөздер: ақылды жылыжай, баға-сапа критериі, анық емес логикалық контроллер (АЕЛК), WSN, IoT, ESP 32, Matlab.

\author{
${ }^{1}$ Б.А. Бельгибаев, ${ }^{2}$ В.В. Никулин, ${ }^{3}$ А.А. Умаров \\ ${ }^{1}$ д.т.н., доцент, Казахский национальный университет им. аль-Фараби, \\ г. Алматы, Казахстан, E-mail: bbelgibaev@list.ru \\ ${ }^{2}$ доктор $\mathrm{PhD}$, ассоциативный профессор, Нью-Йоркский государственный университет, \\ г. Бингамтон, США, E-mail: vnikulin@binghamton.edu \\ ${ }^{3} \mathrm{PhD}$ докторант, Казахский национальный университет им. аль-Фараби, \\ г. Алматы, Казахстан, E-mail: uaa_77@mail.ru
}

\title{
Проектирование смарт теплицы, удовлетворяющей критерию цена-качество
}

Смарт теплица - это революция в сельском хозяйстве, которая создает саморегулирующийся микроклимат, подходящий для роста растений, благодаря использованию датчиков, исполнительных механизмов и систем контроля и управления, которые оптимизируют условия роста и автоматизируют процесс выращивания. Мировой рынок смарт теплиц оценивался примерно в 680,3 млн долларов США в 2016 году и, как ожидается, достигнет примерно 1,31 млрд долларов США к 2022 году, увеличившись в среднем на 14,12\% в период между 2017 и 2022 годами.

Однако высокие цены на установку и высокие первоначальные инвестиционные затраты могут сдерживать внедрение теплиц во многих слаборазвитых и развивающихся странах. Поэтому актуальной задачей является разработка и внедрение доступных широкому населению смарт теплиц, посезонно или круглогодично обеспечивающих население овощами и фруктами. Повышение качества обслуживания теплиц, мониторинг и управление процессов микроклимата возможно за счет применения Програмируемых логических конт- 
роллеров, современных смарт, беспроводных и веб технологии WSN и IoT.

Статья посвящена проектированию системы "Домашняя смарт теплица", устройство управления которой реализовано на базе нечеткого логического контроллера (НЛК). Система позволяет выполнять а) контроль (мониторинг) процессов микроклимата в режиме Online; б) нечеткое управление в ручном и автоматическом режиме; в) регулировать параметры трех процессов микроклимата: охлаждение, полив и освещение.

Описанная модель НЛК адекватно отражает процесс управления микроклиматом в теплице. В результате использования системы повышается производительность труда пользователя-фермера, тем самым помогая пользователю-фермеру контролировать процесс роста растения и принимать необходимые меры по уходу за ними.

Разработанная система удовлетворяет критерию цена - качество, то есть является одновременно доступной населению, и в то же время имеет приемлемое качество обслуживания, используя технологии беспроводных сетей и веб (WSN, IoT) и нечеткого управления. Стоимость системы составляет 86.75 (цена не выше минимальной заработной платы казахстанца), экономический эффект от использования системы - 25 , срок окупаемости теплицы - 4 сезона.

Ключевые слова: смарт теплица, критерий цена-качество, нечеткий логический контроллер (НЛK), WSN, IoT, ESP 32, Matlab.

\section{Introduction}

Greenhouse farming is one of the leading branches of agriculture. Public health directly depends on the development of this sector of the economy. Since the development of agriculture is an important problem of each state, huge funds are allocated to this industry. However, the problem of the lack of fresh vegetables/fruits, that is, the problem of import substitution, remains a big problem in many countries [17,22].

Smart greenhouse is a revolution in agriculture, which creates a self-regulating microclimate suitable for plant growth through the use of sensors, actuators and control and management systems that optimize growth conditions and automate the growing process. The global smart greenhouse market was estimated at approximately 680.3 million in 2016 and is expected to reach approximately 1.31 billion by 2022, an increase of $14.12 \%$ on average between 2017 and 2022 [20].

However, high installation prices and high upfront investment costs can constrain greenhouse adoption in many undeveloped and developing countries. Therefore, the urgent task is the development and implementation of smart greenhouses that are suitable for the wider population, which provide the population with vegetables and fruits seasonally or year-round. Improving the quality of service of greenhouses, controlling and monitoring microclimate processes is possible through the use of programmable logic controllers, modern smart, wireless and web technologies WSN and IoT. Therefore, the urgent task is the development and implementation of smart greenhouses that are suitable for the wider population, which provide the population with vegetables and fruits seasonally or year-round. Improving the quality of service of greenhouses, controlling and monitoring microclimate processes is possible through the use of programmable logic controllers, modern wireless and web technologies WSN and IoT [22].

A greenhouse is a closed-type agroecological system in which energy processes are strictly determined by the technological process of growing plants, taking into account the influence of the environment. The complexity of modeling agroecosystem processes is that they include a large number of subsystems of various physical, chemical and biological nature. The general 
scheme of the theoretical model of the plant production process consists of four blocks: energy and mass transfer in the soil-plant-atmosphere system, photosynthesis, respiration, and the processes of growth, development and movement of organic substances inside the plant [10].

Since agricultural systems are extremely complex structures and practically exclude the possibility of analytical solutions, you should use simulation modeling associated with repeated testing of the model with the necessary input data in order to determine their impact on the output criteria for evaluating the system. Simulation is perceived as a "last resort"method. However, in most cases, we recognize the need to resort to this tool, since the studied systems and models are too complex and need to be presented in an accessible and understandable way for the user.

\section{Literature review}

The existing technical solutions of smart greenhouses can be divided into two groups: industrial, which have a high price and are not accessible to the general user, and household (home) ones, which are inexpensive and affordable for the population, but which have limitations on productivity and functionality.

Industrial solutions of leading manufacturers based on the Simatic S7-1200 from Siemens [21] are very expensive (465) and are designed for complex automation, private firms' solutions $[15,25]$ are also not available to the general public (Smart standard VENT - 772), although designed for home use.

The way out of the situation is independent research and development of the project, which makes it possible to choose the necessary functionality and having a product price lower than market ones. Models of solutions using fuzzy control and have various functionalities, such as modelling and simulation [3], monitoring based on Micaz [13], irrigation based on Raspberry Pi [7], monitoring based on ESP 32 [1], processing and analysis of crop data using IoT [8], control based on Arduino Uno [2, 8, 11], fuzzy control [4, 9, 12, 14, 16, 19], adaptive control [6, 19], temperature control of the greenhouse [16], web monitoring [2,11], automatic drip irrigation system [5,23], phytomonitoring [24].

The development of an effective smart system for managing agricultural processes in a greenhouse with a lack of measurement information and a variety of factors affecting the result of regulation is possible based on the apparatus of fuzzy logic (NL) and neural networks (NN). To obtain the input data of the sample, an experiment was carried out on specially developed real equipment of the Home Smart Greenhouse system (the conFigureuration of the system is described in paragraphs 3.1-3.3).

In the work, the Home Smart Greenhouse system is proposed, the control device of which is implemented on the basis of ESP 32 using a fuzzy logic controller (NLC). The previous embodiment of the proposed system is described in [1] and has only the function of monitoring processes in the greenhouse, that is, it lacks a control function using NLC.

The developed system meets the criterion of price - quality, that is, it is simultaneously accessible to the population, and at the same time has an acceptable quality of service, using wireless network technologies and Web WSN, IoT and smart management.

As a result of using the system, the productivity of the farmer user is increased, thereby helping the farmer user control the plant growth process and take the necessary measures to care for them. 


\section{Material and methods}

\subsection{Architecture of the Home Smart Greenhouse system}

The system architecture has three levels (Fig. 1): 1st level - application level. At this level, operations are performed to manage the object and display reports using the interface tools (control buttons, charts, and histograms). 2nd level - the level of processing and data transfer. At this level, data exchange operations between devices are implemented. ESP32 microcontrollers with built-in Wi-Fi and Bluetooth modules are used.

The first module ESP32 (1) acts as a transmitter - it receives a signal from the sensors of the control object and transmits a signal to the second module ESP32 (2), which plays the role of a receiver. The ESP32 (1) and ESP32 (2) modules together perform two-way data exchange, providing measurement and control operations, interacting with the third level. 3rd level is the level of the object. The greenhouse has greenhouse environmental sensors.

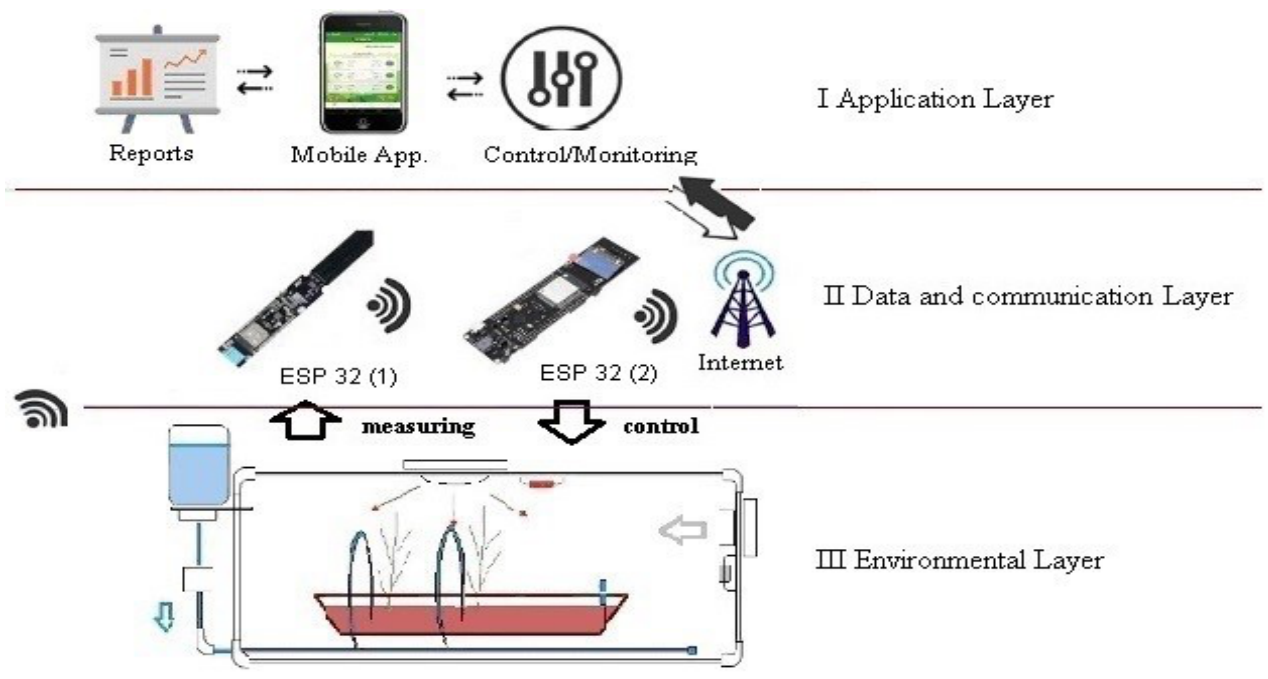

Figure 1: System Architecture

\subsection{Control and management processes in "Home smart greenhouse"}

The control object is a home mini-greenhouse, which considers three technological processes: heating/cooling, lighting and drip irrigation (Fig. 2).

The main element of the system is the control device (CU).

The drip irrigation system works this way. Water is filled in the tank (1). CU (11) controls the water supply (control action $u_{2}$ ), that is, opens/closes the water valve (2) by turning on/off the controller relay. When the valve opens, water flows down (blue arrow), passing through the main pipeline (3) and the dropper (4), and water the plant that is in the pot (brown vessel). Information about the state of soil $x_{2}$ is measured by a moisture sensor (5) and transmitted to the controller, the $\mathrm{CU}$ is received.

The cooling system is described as follows. The CU controls the air supply to the greenhouse, forming the control action $u_{1}$, by turning on/off the fan (6) through the relay. Air 
supply is indicated by a gray arrow. The temperature sensor (7) measures the temperature and air humidity of the greenhouse $x_{1}$ and transmits data to the controller CU.

The lighting system controls the light mode of the greenhouse. The UE generates a control action $u_{3}$, which turns on/off the spotlight (8) via the controller relay. Light intensity data $x_{3}$ is measured by a light sensor (9) and transmitted to the controller CU.

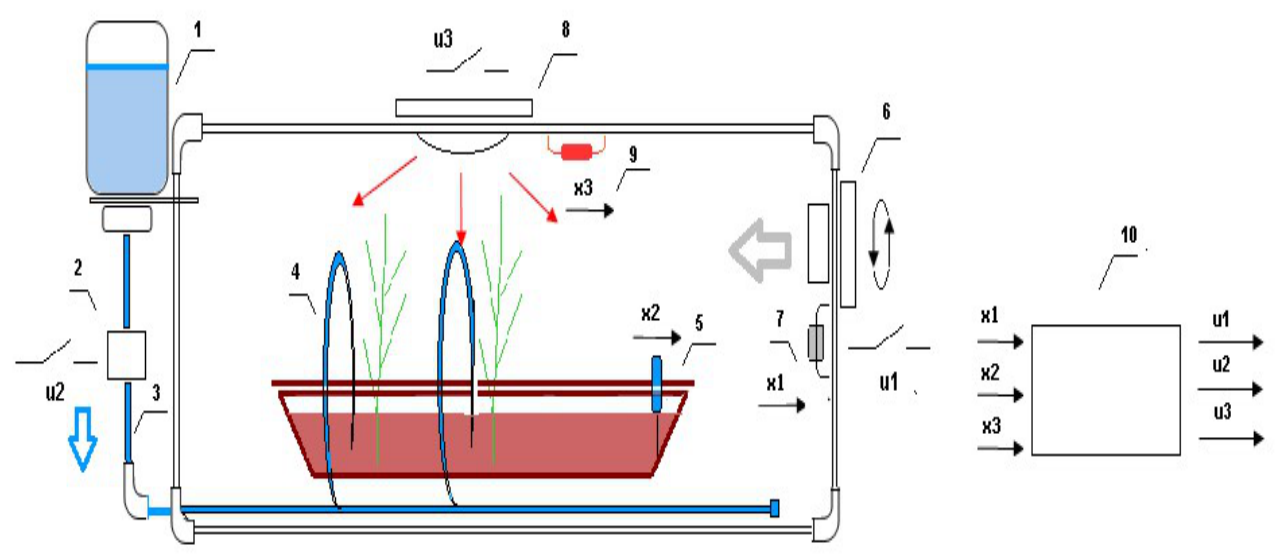

Figure 2: Technological processes in mini greenhouse

\subsection{Control device based on a fuzzy logic controller}

CU implemented on the basis of NLC [18]. A fuzzy inference is an approximation of the "inputs - output" relationship based on linguistic statements like "IF - THEN" and operations on fuzzy sets. The typical structure of the model based on fuzzy inference (NLC) is shown in Fig. 3.

It contains the following blocks:

- a fuzzifier that converts a fixed vector of influencing factors $X$ into a vector of fuzzy sets $\widetilde{X}$ needed to perform fuzzy inference;

- a fuzzy knowledge base containing information about the dependence $Y=f(X)$ in the form of linguistic rules of the type "IF - THEN";

- a machine of fuzzy inference, which, based on the rules of the Knowledge Base, determines the value of the output variable in the form of a fuzzy set $\widetilde{Y}$ corresponding to fuzzy values of the input variables $\widetilde{X}$;

- a defuzzifier that converts the output fuzzy set $\widetilde{Y}$ into a clear number $Y$.

A zero-order Sugeno-type model is considered, in it the relationship between the input variables $X=\left(x_{1}, x_{2}, \ldots, x_{n}\right)$ and the output $y$ is determined by the following fuzzy knowledge base:

$$
\operatorname{IF}\left(x_{1}=a_{1, j 1}\right) \quad \mathrm{AND}\left(x_{2}=a_{2, j 1}\right) \quad \mathrm{AND} \ldots \mathrm{AND}\left(x_{n}=a_{n, j 1}\right)
$$




$$
\begin{aligned}
& \mathrm{OR}\left(x_{1}=a_{1, j 2}\right) \quad \mathrm{AND}\left(x_{2}=a_{2, j 2}\right) \text { AND } \ldots \text { AND }\left(x_{n}=a_{n, j 2}\right) \\
& \ldots \\
& \mathrm{OR}\left(x_{1}=a_{1, j k(j)}\right) \text { AND }\left(x_{2}=a_{2, j k(j)}\right) \text { AND } \ldots \text { AND }\left(x_{n}=a_{n, j k(j)}\right)
\end{aligned}
$$

where $a_{1, j p}$ is the linguistic term by which the variable in the line with the number $j p$ $\left(p=\overline{1, k_{j}}\right)$ is evaluated; $k_{j}$ - the number of lines - conjunctions in which the output $y$ is evaluated by a linguistic term $b_{j} ; m$ is the number of terms used to linguistically evaluate the output variable $y$.

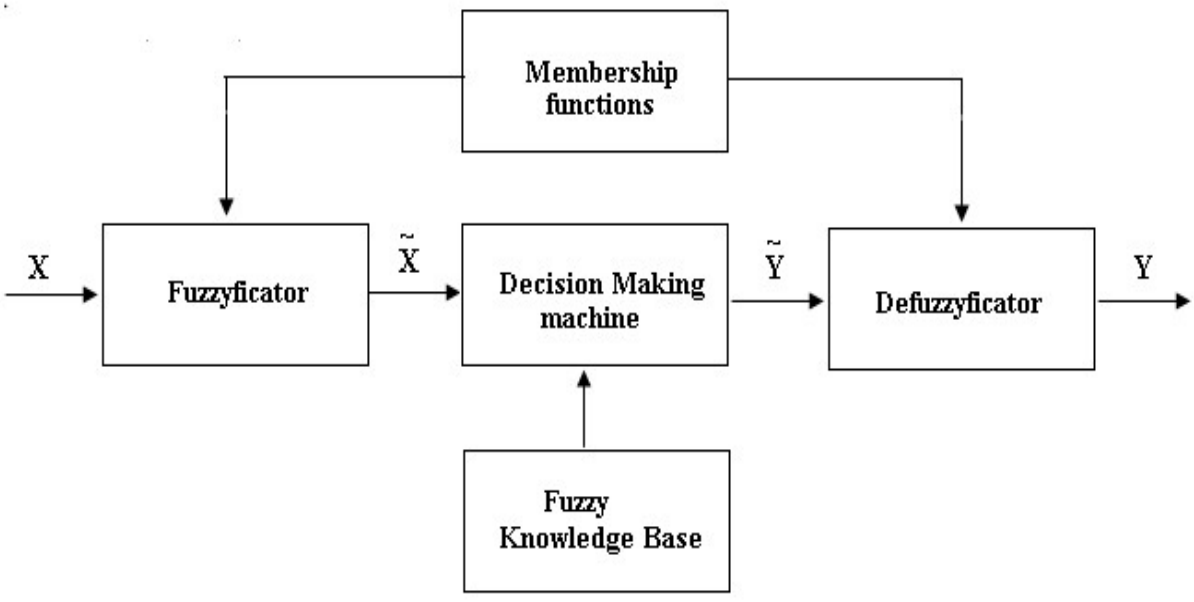

Figure 3: NLC structure

Using the operation (OR) and (AND), we will rewrite the fuzzy Knowledge Base in a more compact form:

$$
\bigcup_{p=1}^{k_{j}} \bigcap_{i=1}^{n}\left(x_{i}=a_{i, j p}\right) \rightarrow y=b_{j}, \quad j=\overline{1, m} .
$$

All linguistic terms in the Knowledge Base (2) are represented as fuzzy sets defined by the corresponding membership functions.

Fuzzy term membership function of $x_{i}$ is

$$
\begin{aligned}
& a_{1, j p}, \quad i=\overline{1, n}, j=\overline{1, m}, p=\overline{1, k_{j}}: \\
& a_{1, j p}=\int_{\underline{x_{i}}}^{\overline{x_{i}}} \mu_{j p}\left(x_{i}\right) / x_{i}, \quad x_{i} \in\left[\underline{x_{i}}, \overline{x_{i}}\right]
\end{aligned}
$$

The degree of belonging of the input vector $X^{*}=\left(x_{1}^{*}, x_{2}^{*}, \ldots, x_{n}^{*}\right)$ to fuzzy terms $d_{j}$ from the Knowledge Base (2) is determined by the following system of fuzzy logical equations:

$$
\mu_{d, j}\left(X^{*}\right)=\bigwedge_{p=\overline{1, k j}} \bigvee_{i=\overline{1, n}}\left[\mu_{j p}\left(x_{i}^{*}\right)\right], \quad j=\overline{1, m}
$$


where $\wedge(\vee)$ is the operation from the $s$-norm $(t$-norm), that is, from the set of implementation: for the operation OR (AND). The following operations are most often used: OR finding the maximum, AND - finding the minimum.

The output of model $\mathrm{y}$ is determined by a linear combination:

$$
y=b_{j, 0}+b_{j, 1} \cdot x_{1}+b_{j, 2} \cdot x_{2}+\ldots+b_{j, n} \cdot x_{n}, \quad j=\overline{1, m},
$$

where $b_{j, i}$ are some numbers.

In the model under consideration (Zero-order Sugeno), the conclusions of the Knowledge Base rules are given by functions in which all the coefficients of the input variables in the linear "input-output" laws are equal to zero. The output of model $(2)-(4) y=b_{j}, j=\overline{1, m}$ correspond to the control signals $u_{1}(t), u_{2}(t), u_{3}(t)$ of the NLC (Fig. 2 and 3), i.e.

$$
y=\left\{u_{1}(t) ; u_{2}(t) ; u_{3}(t)\right\} .
$$

Let us consider in more detail the operation algorithm of the control unit. The basis of $\mathrm{UU}$ is the Knowledge Base, which contains the Databases and the Rule Base. The initial Rule Base is set by an expert. The process of the system includes three stages: Monitoring data; Signal transmission via WiFi/Bluetooth; Management (data processing using NLC).

At the first start-up, in the conditions of an operating greenhouse, the Database is filled with actual values characterizing the state of the microclimate. After filling in the database of previous states and the rule base, the system goes into the operating mode of controlling the microclimate of the greenhouse.

Table 1 provides a description of the linguistic variables of the model $(2)-(5)$. The model has 5 inputs and 3 outputs. Since air temperature and air humidity are measured by one DHT11 sensor, these two physical quantities are denoted by the same variable $x_{1}(t)$. The fourth variable is the start time of the irrigation system $t_{z} a p$.

\begin{tabular}{|c|c|c|c|}
\hline $\begin{array}{l}\text { Linguistic vari- } \\
\text { ables }\end{array}$ & $\begin{array}{l}\text { Variable Range } \\
\text { and their intervals }\end{array}$ & $\begin{array}{l}\text { Type of member- } \\
\text { ship function }\end{array}$ & $\begin{array}{l}\text { Variable designa- } \\
\text { tion }\end{array}$ \\
\hline \multicolumn{4}{|c|}{ In p u t s $-X=\left\{x_{1}(t), x_{2}(t), x_{3}(t), t\right\}$} \\
\hline $\begin{array}{l}\text { Air temperature } \\
\text { (air_temp), } C\end{array}$ & $\begin{array}{l}L=[10,12,18] \\
Z=[16,20,24] \\
H=[22,28,30]\end{array}$ & Triangular & $x_{1}(t)^{*}$ \\
\hline $\begin{array}{l}\text { Air_humidity } \\
\text { (air_hum) } \%\end{array}$ & $\begin{array}{l}\mathrm{L}=[40,42,60] ; \\
\mathrm{Z}=[45,55,65] ; \\
\mathrm{H}=[50,68,70]\end{array}$ & Triangular & $x_{1}(t)^{*}$ \\
\hline Light (light), lk & $\begin{array}{l}\mathrm{L}=[100,150,500] ; \\
\mathrm{Z}=[300,450,600] ; \\
\mathrm{H}=[400,750,800]\end{array}$ & Triangular & $x_{2}(t)$ \\
\hline $\begin{array}{l}\text { Irrigation time } \\
\text { (uakit), hour }\end{array}$ & $\begin{array}{l}\text { t_zap }=20: 00 ; \\
\text { (Runs at 20:00) }\end{array}$ & Singleton & $t$ \\
\hline $\begin{array}{l}\text { Soil_humidity } \\
\text { (top_hum), } \%\end{array}$ & $\begin{array}{l}\mathrm{L}=[40,45,60] ; \\
\mathrm{Z}=[50,65,80] ; \\
\mathrm{H}=[70,85,90]\end{array}$ & Triangular & $x_{3}(t)$ \\
\hline
\end{tabular}

Table 1: Linguistic variables and their scope 


\begin{tabular}{|lc|l|l|l|}
\hline \multicolumn{5}{|c|}{ O u t p u t s $-y=\left\{u_{1}(t) ; u_{2}(t) ; u_{3}(t)\right\}$} \\
\hline $\begin{array}{l}\text { Actuator } \\
\text { On/Off }\end{array}$ & 1, & $\{0 ; 1\}$ & Singleton & $u_{1}(t)$ \\
\hline $\begin{array}{l}\text { Actuator } \\
\text { On/Off }\end{array}$ & 2, & $\{0 ; 1\}$ & Singleton & $u_{2}(t)$ \\
\hline $\begin{array}{l}\text { Actuator } \\
\text { On/Off }\end{array}$ & 3, & $\{0 ; 1\}$ & Singleton & $u_{3}(t)$ \\
\hline
\end{tabular}

The purpose of the NLC is to develop control actions $u_{1}(t), u_{2}(t), u_{3}(t)$ for the corresponding actuator based on the monitoring data $x_{1}(t), x_{2}(t), x_{3}(t)$ and the built-in rules of the Expert Knowledge Base described in Table 2.

Table 2: Rules from the Knowledge Base

\begin{tabular}{|l|l|l|}
\hline & IF & THEN \\
\hline Rule 1 & air_temp is Low AND air_hum is Hi & Actuator 1 is On \\
\hline Rule 2 & air_temp is Hi AND air_hum is Low & Actuator 1 is Off \\
\hline Rule 3 & light is Hi AND uaqit is NOT K & Actuator 2 is Off \\
\hline Rule 4 & light is Low AND uaqit is NOT K & Actuator 2 is On \\
\hline Rule 5 & $\begin{array}{l}\text { air_temp is Low AND air_hum is Hi } \\
\text { AND top_hum is Hi AND uaqit is K }\end{array}$ & Actuator 3 is Off \\
\hline Rule 6 & $\begin{array}{l}\text { air_temp is Hi AND air_hum is Low } \\
\text { AND top_hum is Low AND uaqit is K }\end{array}$ & Actuator 3 is On \\
\hline
\end{tabular}

Table 3 shows the results of monitoring using the system "Home smart greenhouse". They are obtained using the signal sensors of the ESP 32 Transmitter (see paragraphs 2.3 and 2.4). The monitoring process was carried out for 162 hours (database update frequency - every 3 hours).

Table 3: Monitoring results using the "Home smart greenhouse" system

\begin{tabular}{|l|l|l|l|l|}
\hline $\begin{array}{l}\text { Air tempera- } \\
\text { ture, }\end{array}$ & $\begin{array}{l}\text { Air humidity, } \\
\%\end{array}$ & Light, lk & $\begin{array}{l}\text { Soil humidity, } \\
\%\end{array}$ & $\begin{array}{l}\text { Irrigation } \\
\text { time }(h)\end{array}$ \\
\hline 16 & 63 & 0 & 55 & 0 \\
\hline 15 & 70 & 0 & 58 & 3 \\
\hline 13 & 82 & 136 & 52 & 6 \\
\hline 14 & 82 & 375 & 48 & 9 \\
\hline 17 & 66 & 476 & 42 & 12 \\
\hline 18 & 64 & 524 & 40 & 15 \\
\hline 19 & 65 & 497 & 45 & 18 \\
\hline 20 & 56 & 464 & 66 & 21 \\
\hline 14 & 44 & 0 & 62 & 24 \\
\hline 14 & 68 & 0 & 60 & 0 \\
\hline 13 & 73 & 0 & 57 & 3 \\
\hline
\end{tabular}




\begin{tabular}{|c|c|c|c|c|}
\hline 13 & 68 & 117 & 52 & 6 \\
\hline 18 & 60 & 321 & 55 & 9 \\
\hline 20 & 59 & 476 & 50 & 12 \\
\hline 20 & 57 & 424 & 51 & 15 \\
\hline 20 & 65 & 222 & 62 & 18 \\
\hline 14 & 60 & 316 & 81 & 21 \\
\hline 15 & 78 & 0 & 72 & 24 \\
\hline 15 & 78 & 0 & 70 & 0 \\
\hline 14 & 73 & 0 & 65 & 3 \\
\hline 13 & 70 & 117 & 60 & 6 \\
\hline 20 & 58 & 321 & 58 & 9 \\
\hline 22 & 54 & 408 & 55 & 12 \\
\hline 21 & 63 & 363 & 48 & 15 \\
\hline 20 & 65 & 190 & 53 & 18 \\
\hline 19 & 58 & 460 & 68 & 21 \\
\hline 14 & 74 & 0 & 64 & 24 \\
\hline 14 & 74 & 0 & 63 & 0 \\
\hline 11 & 70 & 0 & 60 & 3 \\
\hline 11 & 61 & 195 & 57 & 6 \\
\hline 18 & 49 & 536 & 50 & 9 \\
\hline 22 & 44 & 680 & 45 & 12 \\
\hline 24 & 41 & 606 & 50 & 15 \\
\hline 24 & 42 & 318 & 53 & 18 \\
\hline 21 & 56 & 470 & 58 & 21 \\
\hline 13 & 55 & 0 & 62 & 24 \\
\hline 13 & 55 & 0 & 60 & 0 \\
\hline 12 & 44 & 0 & 57 & 3 \\
\hline 10 & 39 & 195 & 54 & 6 \\
\hline 20 & 38 & 536 & 49 & 9 \\
\hline 26 & 31 & 680 & 45 & 12 \\
\hline 27 & 32 & 606 & 48 & 15 \\
\hline 27 & 36 & 593 & 47 & 18 \\
\hline 25 & 48 & 568 & 52 & 21 \\
\hline 16 & 45 & 0 & 55 & 24 \\
\hline 16 & 45 & 0 & 57 & 0 \\
\hline 16 & 44 & 0 & 60 & 3 \\
\hline 15 & 38 & 195 & 63 & 6 \\
\hline 24 & 32 & 536 & 60 & 9 \\
\hline 28 & 31 & 680 & 53 & 12 \\
\hline 29 & 29 & 363 & 50 & 15 \\
\hline 20 & 42 & 338 & 55 & 18 \\
\hline 16 & 59 & 316 & 81 & 21 \\
\hline 19 & 37 & 0 & 78 & 24 \\
\hline
\end{tabular}




\section{Results and discussions}

The simulation results are reflected in the form of the NLC structure (Fig. 4), the rules of the Knowledge Base (Fig. 5), the values of the fuzzy logical inference of the system for three IM1, IM2 and IM3 (Fig. 6, 7, 8 and 9).

NLC is a Multi Input Multi Output (MIMO) system in which there are 5 inputs and 3 outputs (Fig. 4). Inputs: Air Temperature, Humidity, Illumination, Soil Humidity and Watering Time. Outputs: state IM1, IM2 and IM3 (see Table 2). The Knowledge Base contains 6 rules (see Table 3 ).

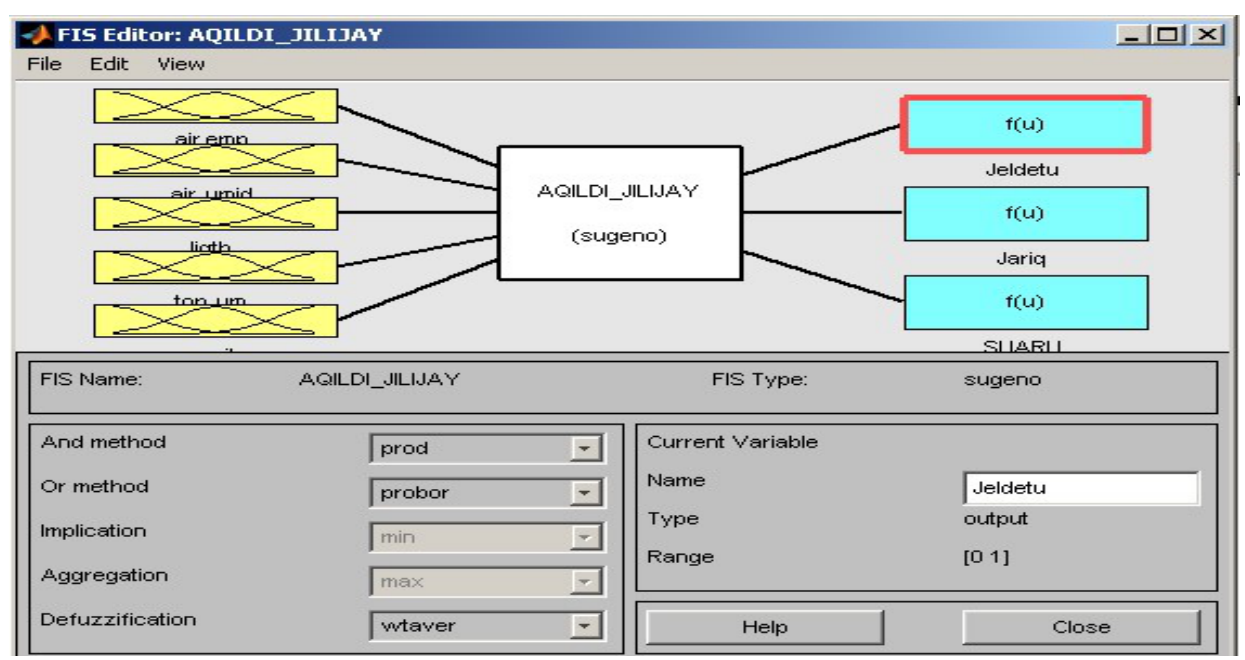

Figure 4: The structure of the NLC model in Matlab

An example of creating a Knowledge Base based on Table 3 in the Matlab environment is shown in Fig. 5. Here the variable On means to turn on the corresponding IM, the variable Off to turn off the corresponding IM.

Let us explain the calculated control values in Fig. 6-9.

For example, with an input vector $x_{1}=\{15.12 ; 66.71 ; 620.7 ; 69.88 ; 12.06\}$ NLC output $y_{1}=\left\{u_{1}=0 ; u_{2}=0.5 ; u_{3}=0\right\}$ (rule 1 is fulfilled, that is, at low air temperature and high air humidity - the fan must be turned off and rule 3, that is, at high daylight - the projector must be turned off).

With the input vector $x_{2}=\{27.32 ; 44.02 ; 450 ; 65 ; 11.5\}$ NLC output $y_{2}=\left\{u_{1}=\right.$ $\left.0.734 ; u_{2}=0.5 ; u_{3}=0\right\}$ (rule 2 is fulfilled, that is, high air temperature and low air humidity - the fan must be turned on).

With the input vector $x_{3}=\{19.51 ; 55 ; 193.9 ; 65 ; 11.5\}$ NLC output $y_{3}=\left\{u_{1}=0 ; u_{2}=\right.$ $\left.0.5 ; u_{3}=0\right\}$ (rule 4 is satisfied, that is, during the day in low light - the spotlight must be turned on).

For example, with an input vector $X 4=\{27.8 ; 44.76 ; 193.9 ; 46.71 ; 22.16\}$ NLC output $y 4=\left\{u_{1}=0.53 ; u_{2}=0.5 ; u_{3}=0\right\}$ (rule 2 is fulfilled, that is, at high air temperature and low air humidity - the fan must be turned on and rule 6 , that is, at high air temperature and low air humidity and low soil moisture after 20:00 hours - the irrigation valve must be enable). 
Monitoring data (input vector) for 162 hours are shown in Fig. 10-A in the form of graphs. The values of the logical output of the NLC (output vector) - control signals of actuators are shown in Fig. 10-B - in graphs.

In Fig. 11 shows the monitoring process using the mobile application of the Home Smart Greenhouse system in ONLINE mode.

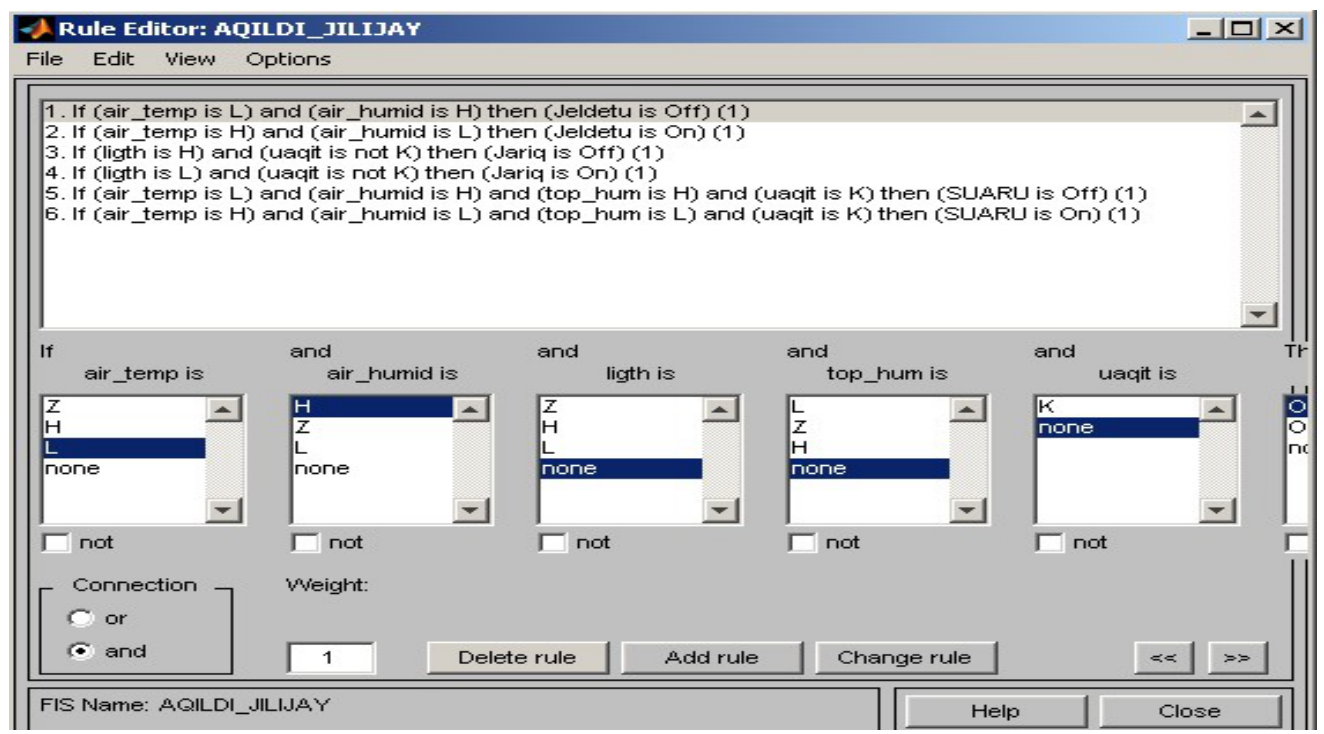

Figure 5: Rules from the NLC Knowledge Base in the Matlab environment

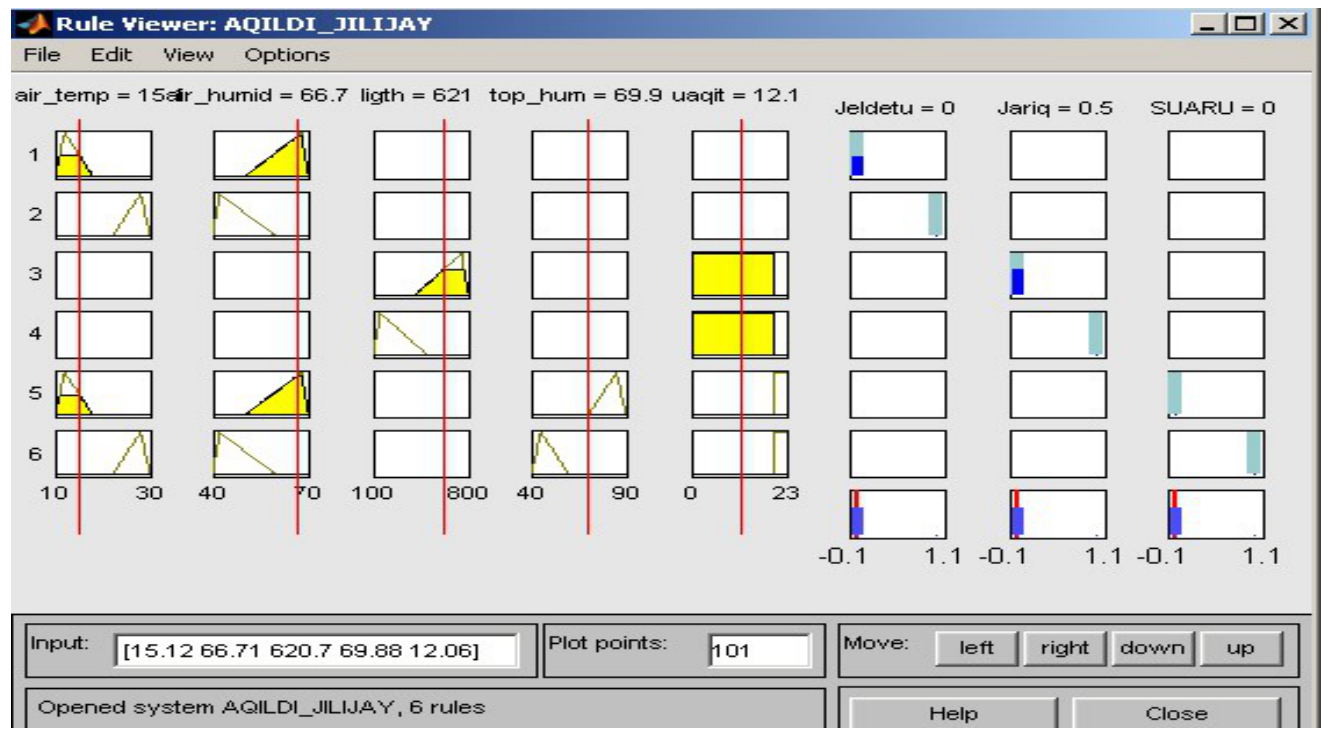

Figure 6: NLC fuzzy output: rules 1 are complied with (Fan off) and rule 3 (Spotlight off) 


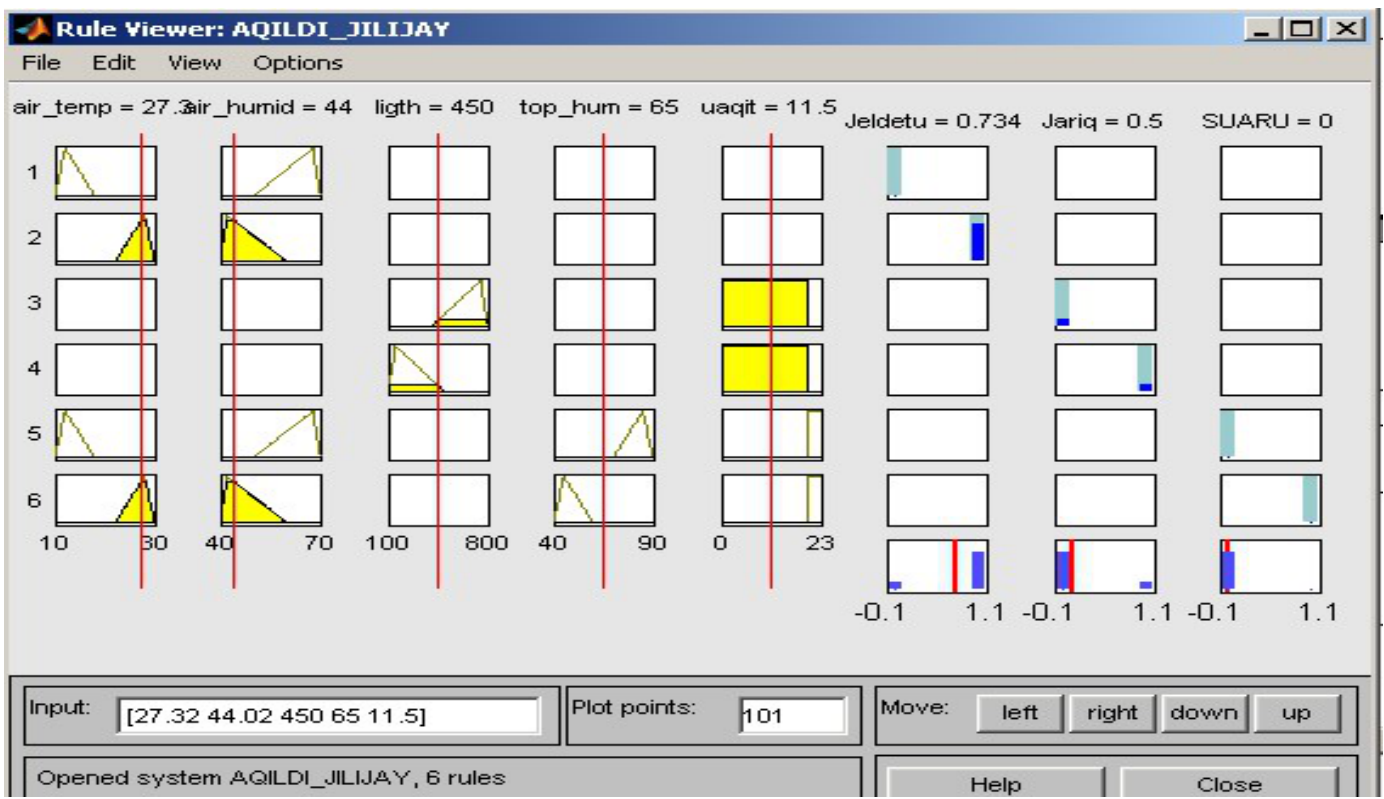

Figure 7: Fuzzy NLC output: rule 2 is fulfilled (Fan is on)

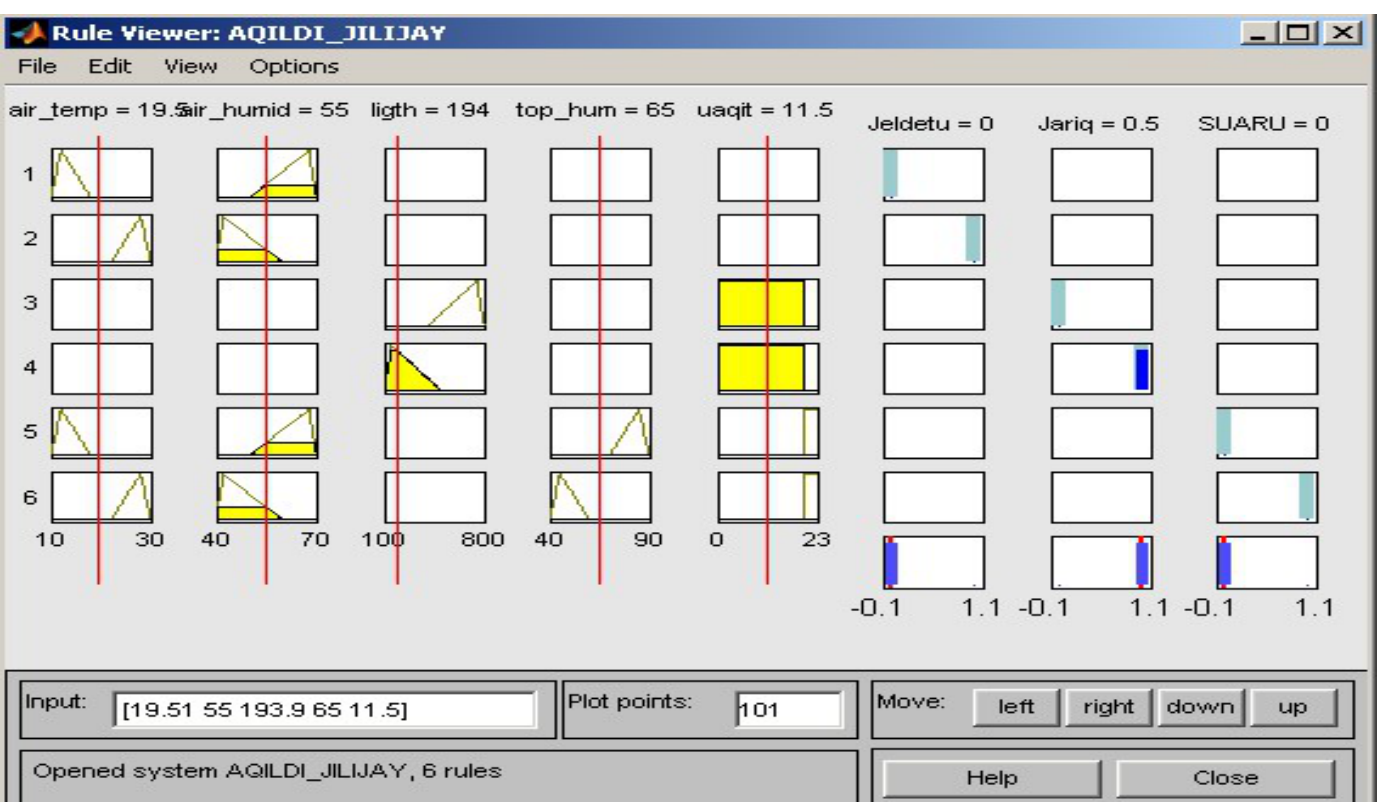

Figure 8: Fuzzy NLC output: rule 4 is fulfilled (Spotlight is on) 


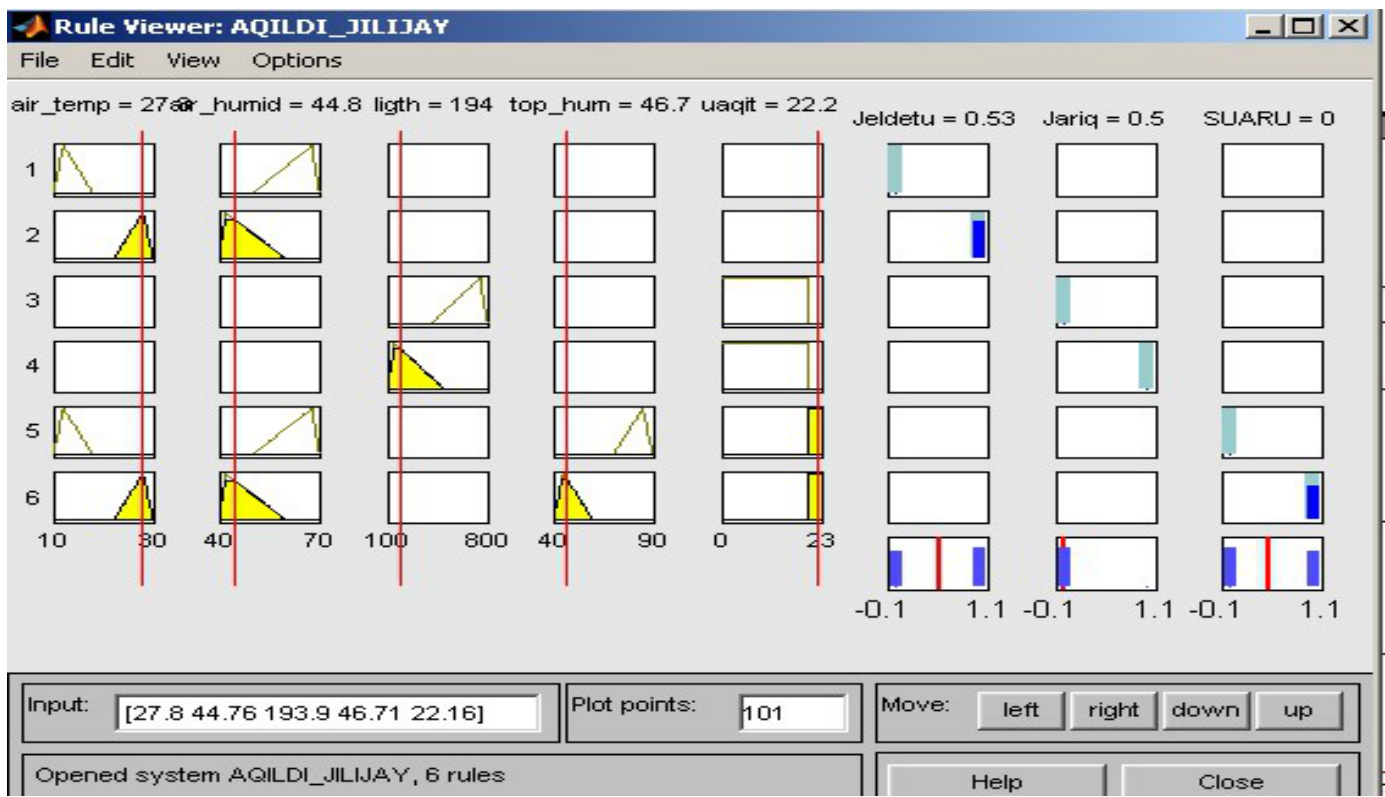

Figure 9: Fuzzy NLC output: rule 2 is fulfilled (fan is on) and rule 6 (watering valve on)
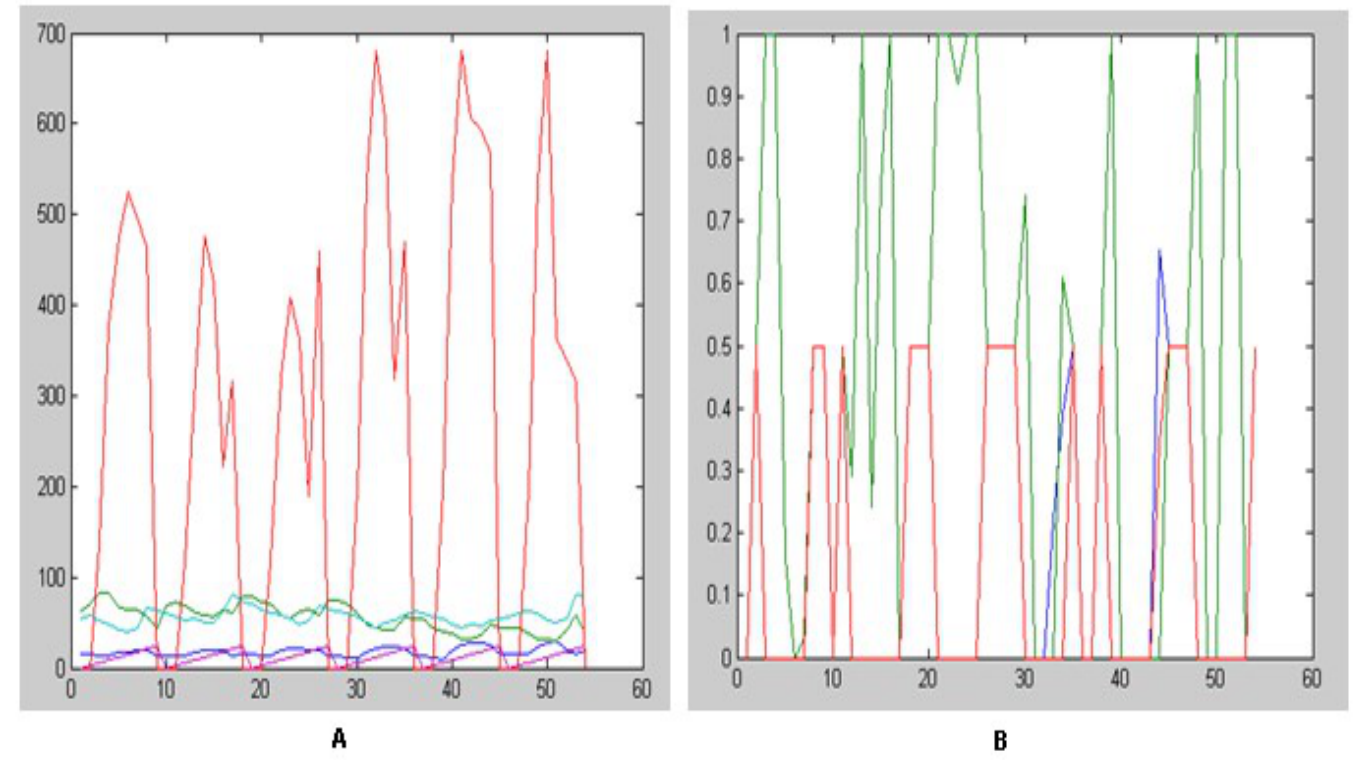

Figure 10: A - Monitoring data for 162 hours; B - the logical output of the NLC (output vector) - control signals of actuators 


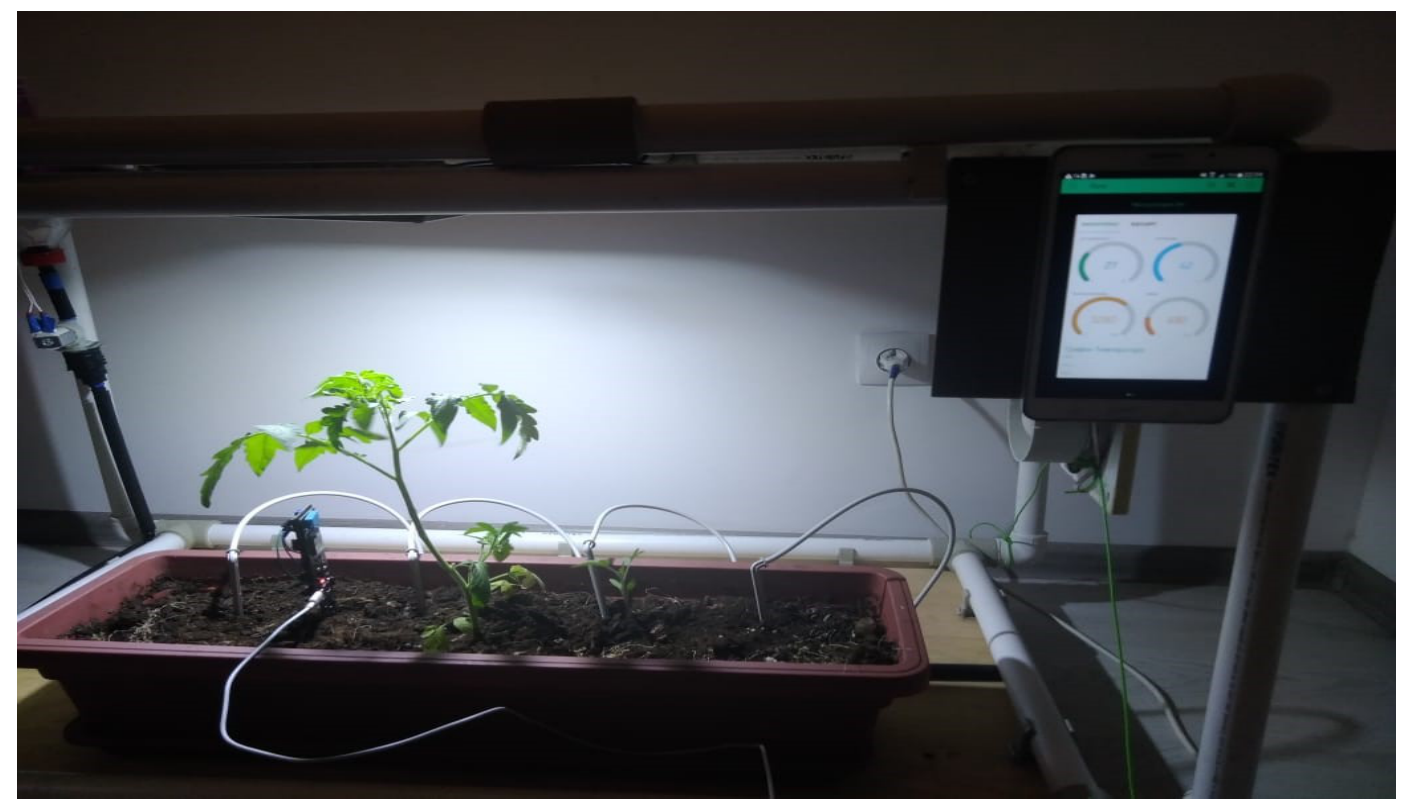

Figure 11: Mobile application "Akyldy zhylyzhay", in the process of work

\section{Conclusion}

The paper proposes an approach to the development of the Home Smart Greenhouse system, the control device of which is implemented on the basis of NLC in the form of the Sugeno model. The system allows you to perform:

1) control (monitoring) of the microclimate processes in Online mode;

2) fuzzy control in manual and automatic mode;

3) adjust the parameters of the three microclimate processes: cooling, watering and lighting.

The main element of the system is a control device based on NLC. The device is based on the ESP 32 microcontroller using wireless networks and web technology (WSN, IoT) and fuzzy control.

The described NLC model adequately reflects the microclimate control process in the greenhouse. As a result of using the system, the productivity of the farmer user is increased, thereby helping the farmer user control the plant growth process and take the necessary measures to care for them.

The developed system meets the criterion of price-quality. The cost of the system is 86.75 (the price is not higher than the minimum wage of Kazakhstan), the economic effect of using the system is 25 , the payback period of the greenhouse is 4 seasons. 


\section{References}

[1] Amantur Umarov, Murat Kunelbayev, Maksat Satymbekov et al., "Micro climate Monitoring System For A Home Greenhouse As Part Of ESP32", International Conference on Renewable Energy ES Emerging Technologies (ICREET) 2019. doi:0.1617/vol6iss11pid101035.

[2] Carlos Robles, Jesús Callejas, Aura Polo, "Low-Cost Fuzzy Logic Control for Greenhouse Environments with Web Monitoring", Electronics 6, 71, 2017. doi:10.3390/electronics6040071.

[3] Didi Faouzi, N. Bibi-Triki, B. Draoui, A. Abene, "Modeling and simulation of fuzzy logic controller for optimization of the greenhouse microclimate management", Agricultural science and technology Vol. 9, No 2, 2017. doi: 10.15547/ast.2017.02.024.

[4] Doaa M. Atia, Hanaa T., "El-madany Analysis and design of greenhouse temperature control usingadaptive neuro-fuzzy inference system", Journal of Electrical Systems and Information Technology 4 (2017): 34-48.

[5] Georgios Nikolaou, Damianos Neocleous, Nikolaos Katsoulas, Constantinos Kittas, "Irrigation of Greenhouse Crops" Horticulturae 5, 7, 2019. doi:10.3390/horticulturae5010007.

[6] Giuseppina Nicolosi, Roberto Volpe, Antonio Messineo, "An Innovative Adaptive Control System to Regulate Microclimatic Conditions in a Greenhouse", Energies 10, 722, 2017. doi:10.3390/en10050722.

[7] Ishak S.N., Abd Malik N.N., Abdul Latiff N.M. et. al. "Smart Home Garden Irrigation System Using Raspberry Pi", IEEE 13th Malaysia International Conference on Communications (MICC) (2017).

[8] Jirapond Muangprathub, Nathaphon Boonnam, Siriwan Kajornkasirat, Narongsak Lekbangpong, Apirat Wanichsombat, Pichetwut Nillaor, "IoT and agriculture data analysis for smart farm", Computers and Electronics in Agriculture 156 (2019): 467-474.

[9] Kais Said, Qays Jebur, "Design a Multi-Choice Fuzzy Control System of the Greenhouse" , Journal of Engineering Volume 21-2 (2015): 103-118.

[10] Klapwijk D., "Kasklimaat plantengroei en groeibeheersing onder glas [Microclimate and plant growth management]", Amsterdam: Elsevier (1971).

[11] Lukas Bajer, Ondrej Krejcar, "Design and Realization of Low Cost Control for Greenhouse Environment with Remote Control" , IFAC-PapersOnLine 48-4 (2015): 368-373.

[12] Manel Jomaa, Mehdi Abbes, Fernando Tadeo, Abdelkader Mami, "Greenhouse Modeling, Validation and Climate Control based on Fuzzy Logic", Engineering, Technology \&S Applied Science Research Vol. 9, No. 4 (2019): 4405-4410.

[13] Mustafa Alper Akkaç, Radosveta Sokullu, "An IoT-based greenhouse monitoring system with Micaz motes" , Procedia Computer Science 113 (2017): 603-608

[14] Rafiuddin Syam, Wahyu H. Piarah and Budi Jaelani, "Controlling Smart Green House Using Fuzzy Logic Method", International Journal on Smart Material and Mechatronics Vol. 2 No. 2 (2015).

[15] Reallab, "Sistema kontrolya i upravleniya mikroklimatom v ovoshchekhranilishche "Agroterm" [Climate control and management system in the vegetable store "Agroterm"]", Nauchno-issledovatel'skaya laboratoriya avtomatizacii i proektirovaniya Automation and Design Research Laboratory] https://www.reallab.ru/.

[16] Revathi S., Sivakumaran N., "Fuzzy Based Temperature Control of Greenhouse" , IFAC-PapersOnLine 49 (1) (2016) 549-554.

[17] Richard Grabowski, "The failure of import substitution: Reality and myth", Journal of Contemporary Asia Vol. 24, Issue 3, 1994. https://doi.org/10.1080/00472339480000181.

[18] Shtovba S.D., "Proektirovanine nechenkih sistem sredstvami Matlab [Designing fuzzy systems using Matlab]", Moscow: Telekom (2007).

[19] Mohamed S., Hameed I.A., "A GA-Based Adaptive Neuro-Fuzzy Controller for Greenhouse Climate Control System", Alexandria Engineering Journal 57 (2015): 773-779.

[20] "Smart greenhouse last edited 16 Sep 2018, https://www.designingbuildings.co.uk/wiki/Smart_greenhouse.

[21] Siemens AG 2018, Greenhouse control with Simatic S7-1200. Entry ID: 109757060, Vol 1, 05/2018. http://www.support.industry.siemens.com/cs/ww/en/view/109757060. 
[22] Umarov A., "Auildin ruhani jangirui: shagin jilijaylar [Spiritual revival of the village: mini greenhouses]", "Kazakh uni" Respublicalik kogamdik saiasi gazeti-ulttik portal ["Kazakh uni"republican social newspaper-national portal], last edited 17 July 2018. https://qazaquni.kz/2018/07/17/87636.html.

[23] Usman Ahmad, Dwa Made Subrata and Chusnul Arif, "Speaking Plant Approach for Automatic Fertigation System in Greenhouse", International Journal of Signal Processing, Image Processing and Pattern Recognition Vol. 4, Issue 3 (2011).

[24] Uwe Schuch, Dennis Danneh, "Microclimate control in greenhouses based on phytomonitoring data" , Humboldt University of Berlin, Biosystem Engineering division (2013).

[25] Viktor Petin, "Arduino i Raspberry Pi v proektah Internet of Things [Arduino and Raspberry Pi in Internet of Things projects]", Sankt-Peterburg, 2016. http://www.bhv.ru. 